\title{
Ectocommensal and ectoparasites in goldfish Carassius auratus (Linnaeus, 1758) in farmed in the State of Sáo Paulo
}

\author{
Ectocomensais e ectoparasitas em kinguios Carassius auratus (Linnaeus, 1758) \\ criados em fazenda no Estado de São Paulo \\ Carla Renata Serantoni Moyses ${ }^{1}$; Diva Denelle Spadacci-Morena²; \\ José Guilherme Xavier ${ }^{1}$; Antonio Mataresio Antonucci³; Maria Anete Lallo ${ }^{1 *}$
}

1Pós-Graduação em Patologia Ambiental e Experimental, Universidade Paulista - UNIP, São Paulo, SP, Brasil
${ }^{2}$ Laboratório de Fisiopatologia, Instituto Butantan, São Paulo, SP, Brasil
${ }^{3}$ Disciplina de Parasitologia Veterinária, Faculdade de Medicina Veterinária - FAEF, Garça, SP, Brasil

Received January 16, 2015

Accepted May 18, 2015

\begin{abstract}
Concomitant infections by several parasitic genera are rare, very debilitating and often lethal to fish reared under commercial breeding conditions. Were describe a multiple and concurrent parasite infestation in cultured goldfish Carassius auratus with skin damage (nodules and/or ulceration). Fish with skin lesions underwent necropsy, and the skin and gills were scraped and examined. Histopathological examination with Hematoxylin-Eosin and Giemsa stain, and an ultrastructure study using transmission and scanning electron microscopy were conducted. In the skin, we identified multiple-parasite infestations by Gyrodactylidae, Epistylis sp., Trichodina sp., Ichthyophthirius multifliiis, Tetrahymena sp. and Ichthyobodo necator, associated with epithelial cell hyperplasia and epidermal sloughing. Although no gross lesions were observed, were identified a large number of parasites in the gills (Epistylis sp., Piscinoodinium sp., Ichthyophthirius multifliis, Trichodina sp., Apiosoma sp., Hexamita sp. and cysts of a trematode digenean). The observed trematodes were not identified. The associated microscopic lesions were epithelial hypertrophic and hyperplasic and exhibited fusion of secondary lamellae and epithelial cell detachment. This is the first description of a protozoan Vorticella sp. parasitizing goldfish in Brazil. Multiple ectoparasitism by protozoa and Platyhelminthes, with or without apparent tissue damage, can be fatal for goldfish raised on farms with poor management.
\end{abstract}

Keywords: Carassius auratus, digenean trematodes, fish diseases, infection protozoan, parasites.

\section{Resumo}

A infestação concomitante por vários gêneros de parasitas é uma condição rara, debilitante e letal para os peixes e está geralmente associada aos problemas ambientais e de manejo. Com o objetivo de descrever os ectoparasitos presentes em kinguios Carassius auratus com lesóes cutâneas, cultivados em fazenda comercial, foram analisados 30 exemplares de peixes por esfregaços de pele lesionada e de brânquias; exame histopatológico de tecidos corados pela técnica de Hematoxilina-Eosina e Giemsa e estudo ultraestrutural por microscopia eletrônica de transmissáo e varredura de tecidos coletados após necropsia. Nas lesóes cutâneas, foram observados os parasitos: Gyrodactylidae, Epistylis sp., Trichodina sp., Ichthyophthirius multifiliis, Tetrahymena sp. e Ichthyobodo necator, associados à hiperplasia epitelial, descamaçáo epidérmica e presença de infiltrado inflamatório. A infestação das brânquias, mesmo sem lesão macroscópica, evidenciou Epistylis sp., Piscinoodinium sp., I. multifliiis, Trichodina sp., Apiosoma sp., Hexamita sp. e cistos de trematódeo associados à hipertrofia e hiperplasia epitelial, fusão de lamelas secundárias, descamação epitelial e presença de infiltrado inflamatório. Os trematódeos observados não foram identificados. É a primeira descrição do protozoário Vorticella sp. parasitando kinguios no Brasil. O ectoparasitismo múltiplo por protozoários e platelmintos, com ou sem lesão aparente, pode ser fatal em peixes cultivados em condiçóes ambientais precárias.

Palavras-chave: Carassius auratus, trematódeos digenéticos, doenças de peixes, infecção por protozoários, parasitas.

\footnotetext{
*Corresponding author: Maria Anete Lallo. Pós-Graduação em Patologia Ambiental e Experimental, Universidade Paulista - UNIP, Rua Dr. Bacelar, 1212, 4º.andar, CEP 04026-002, São Paulo, SP, Brasil.

e-mail: anetelallo@hotmail.com
} 


\section{Introduction}

The aquarium fish trade is a very important sector worldwide (SILVA \& TURCHINI, 2008). Although ornamental aquaculture is very popular in Brazil, fish production is conducted by intensive farming with rudimentary handling. Fish in aquaculture farms are often subjected to acute or chronic stressors such as handling, transportation, sorting, temperature change, high rearing density and poor water quality. These factors affect fish physiology and their growth, behavior, welfare and reproduction, which cause high mortality and severe economic losses (ASHLEY, 2007; BRINN et al., 2012).

Parasites often cause serious outbreaks of disease in populations of cultured fish, especially when dense populations of fish are kept in improper environmental conditions that may allow certain parasite populations to increase to a very high level (ROBERTS et al., 2009). Protozoans can be ectoparasites or endoparasites, depending on their species, and are the most common parasites encountered in cultured fish (WOO \& BRUNO, 2011; PURIVIROJKUL \& BOONSOONG, 2012). With some exceptions (Ichthyophthirius multifiliis, Chilodonella sp. and Ichthyobodo sp.), external protozoans are not obligate fish parasites and may be found on a variety of surfaces, including on logs, plants and even parasites of other fish parasites. Occasionally, when the environmental quality is very inadequate, some free-living organisms can be found on the surface of fish, promoting the false impression that they are parasites (WOO \& BRUNO, 2011; WOO \& BUCHMANN, 2012).

Many problems occurring in aquaculture and the aquarium industry are generally caused by viral, bacterial, and fungal diseases; however, metazoan ectoparasites, especially the Monogenea and others trematodes, often cause greater losses. Several of the higher taxa of Monogenea have been implicated in causing disease and mortality of fishes. Most of the problems have occurred in intensive aquaculture situations, but there are a few cases in natural populations (ABOWEI et al., 2011; KENT \& FOURNIE., 2007).

To date, several parasitological surveys have been conducted on freshwater and seawater fish and have recorded a very diverse set of parasitofauna. Unfortunately, none of these surveys included cultured aquarium fish, such as goldfish $C$. auratus. This study was to survey the potential parasites of cultured goldfish that are associated with management and environmental conditions.

\section{Materials and Methods}

\section{Water}

To assess the quality of water, company Cascardi Saneamento Básico Ltda. collected samples of 2 liters of water each tank (20 samples), on the same day and time, in properly sanitized and prepared bottles. The samples were sent to the laboratory for the preservation of the material to be analyzed and the analysis of nitrates, nitrites, ammonia nitrogen and $\mathrm{pH}$ performed following the specifications of the Standard Methods for Examination of Water and Wastewather (CLESCERI et al., 1998).
Fish

Goldfish C. auratus were obtained from ornamental fish farm where several fish species were growing together and separated only by age. The farm was located in the municipality of Guararema, State of São Paulo, where there were 20 tanks of creation. In this study, three environmental stressors within tanks were considered: high population density, alkaline $\mathrm{pH}$, and abundance of diet (as high levels of diet are associated with high ammonia content). Fish $(n=30)$ with white or ulcerative skin lesions were collected and transported to the laboratory according to standard procedures (LOM \& DYKOVA, 1992). Fish were housed in tanks with a continuous flow water system at $24 \pm 1^{\circ} \mathrm{C}$ in the aquatic facility of the Paulista University - UNIP (Biotério Modelo SPF e de Peixes). They were fed "ad libitum" for $24 \mathrm{~h}$. Prior to necropsy, fish were anaesthetized by immersion in a $150 \mathrm{mg} / \mathrm{L}$ solution of tricaine methane sulfonate (MS222 Sigma-Aldrich, St. Louis, Misouri, USA) until paralysis of the operculum (NEIFFER \& STAMPER, 2009). The fish ranging from 25 to $39 \mathrm{~g}$ and from 15 to $25 \mathrm{~cm}$. Animals in the aquatic facility were maintained according to the guidelines of the Brazilian National Council for the Control of Animal Experimentation (CONCEA), and all procedures were approved by the ethics committee of the University (number 163/2013).

\section{Collection and processing of specimens for light microscopy}

Damaged skin areas were scraped to collect material for observation under a light microscope. Parasites were identified using morphological parameters (LOM \& DYKOVA, 1992). The body, fins, mouth, eyes and inner capping of each fish were examined for possible parasites. Subsequently, the gills, skin and other organs were removed and fixed in Bouin's solution for 8 hours and kept in $70 \%$ alcohol. These materials were then embedded in paraffin for histological analysis and stained routinely with Hematoxylin-Eosin and Giemsa.

\section{Electron and scanning microscopy}

For electron transmission microscopy (TEM), small pieces of gills and skin lesions were fixed in $2 \%$ glutaraldehyde in $0.2 \mathrm{M}$ cacodylate buffer ( $\mathrm{pH} 7.2$ ) at $4^{\circ} \mathrm{C}$ for $10 \mathrm{~h}$, and post-fixed in $1 \%$ OsO4 buffered for $2 \mathrm{~h}$ and then in $5 \%$ uranyl acetate overnight at $4^{\circ} \mathrm{C}$. The fragments were dehydrated in an ascending ethanol series with propylene oxide and embedded in Spurr resin (EL-MATBOULI \& HOFFMANN, 1996). Blocs were cut, and semi-thin sections were stained with toluidine blue and photographed under a light microscope. Ultrathin sections were double stained with aqueous uranyl acetate and lead citrate and then observed under a ZEISS EM 109 TEM operated at $80 \mathrm{kV}$. Fragments of skin and gills were fixed and dehydrated, as described for TEM. Fragments were then processed in a drying apparatus and subsequently mounted on copper studs and gold coated. These fragments were examined using a JEOL JSM-65 MCA scanning electron microscope (SEM). 


\section{Results}

\section{Water quality}

The water quality analysis indicated that the average $\mathrm{pH}$ of the tanks was $7.95( \pm 0.74)$, and the concentration of ammonia was $0.31( \pm 0.37) \mathrm{mg} / \mathrm{L}$. The levels of nitrates and nitrites $(0.7 \pm 0.15$ and $<0.002$, respectively) were within the normal range.

\section{Lesions}

All animals examined had skin lesions and a thickening of the dermis that was covered with mucus or spots with a cotton wool appearance and necrotic tissue (Figure 1a). In some cases, the ulcerated lesions had a hemorrhagic appearance. Skin lesions were located on the dorsal and lateral sides of the fish, sometimes on fins. Significant epithelial cell hyperplasia and hypertrophy with eventual exhaustion of mucous cells and epidermal sloughing was observed. Because of the enzymes released by some parasites, there was extensive tissue damage with areas of necrosis and muscle impairment under the skin of the affected regions. Inflammatory infiltrate was characterized by the presence of lymphocytes, macrophages and neutrophils in the dermis. The gills showed no macroscopic lesions; however, at histological examination, were observed that the epithelium exhibited several degrees of hyperplasia and detachment of epithelial cells. There were some cases where the hyperplasia was more severe, which resulted in the fusion of some secondary lamellae (Figure 2).

\section{Parasites}

All fish were parasitized (100\%). Eleven genera of ectoparasites were identified, including protozoa, Platyhelminthes Monogenea and metacercarial cysts of Digenea. Multiple infestations was observed on the gills and/or skin, being $30 \%$ of fish (9/30) had 2 or 3 parasite species, $40 \%(12 / 30)$ had 4 parasite species and $30 \%(9 / 30)$ had 5 or more parasite species. The prevalence of parasites in the skin and gills can be seen in Table 1.

In the skin, were observed a not identified Digenea, and the following parasites: Monogenea Gyrodactylidae, Epistylis sp., Vorticella sp., Trichodina sp., Ichthyophthirius multifliis, Tetrahymena sp. and Ichthyobodo necator (Figure 1b-f). In the gills, were founded a not identified digenea and Monogenea Gyrodactylidae, I. multifliis, Vorticella sp., Trichodina sp., Hexamita sp., Piscinoodinium sp. and Apiosoma sp. (Figures 1 and 3).

The peritrichous ciliates Epistylis sp. and Vorticella sp. were present in large numbers in skin lesion, Epistylis sp. was a colonial ciliate with a bell-shaped or conical body (Figures $1 \mathrm{c}$ and $3 \mathrm{~d}$ ) and had a non-contractile stalk that bore multiple zooids. Vorticella sp. was characterized by its inverted bell-shaped body (Figure 1f). They were solitary and had a retractile stalk. The genera Apiosoma sp. was a solitary ciliate with a circular scopula that was directly attached to the gill (Figure 3c).

Trichodina sp. appeared to be a saucer-shaped, hemispheric, dumbbell-shaped, sac-like or flattened cylindrical organism in cross-section. From the oral or aboral view, Trichodina sp. appeared as round discs (Figures $1 \mathrm{~d}$ and $2 \mathrm{~h}, \mathrm{i}$ ). The specie I. multifiliis was large in size (approximately 0.1 to $1.0 \mathrm{~mm}$ ) and had a horse-shaped macronucleus (Figures 1d and 2d). The other genus Tetrahymena sp.
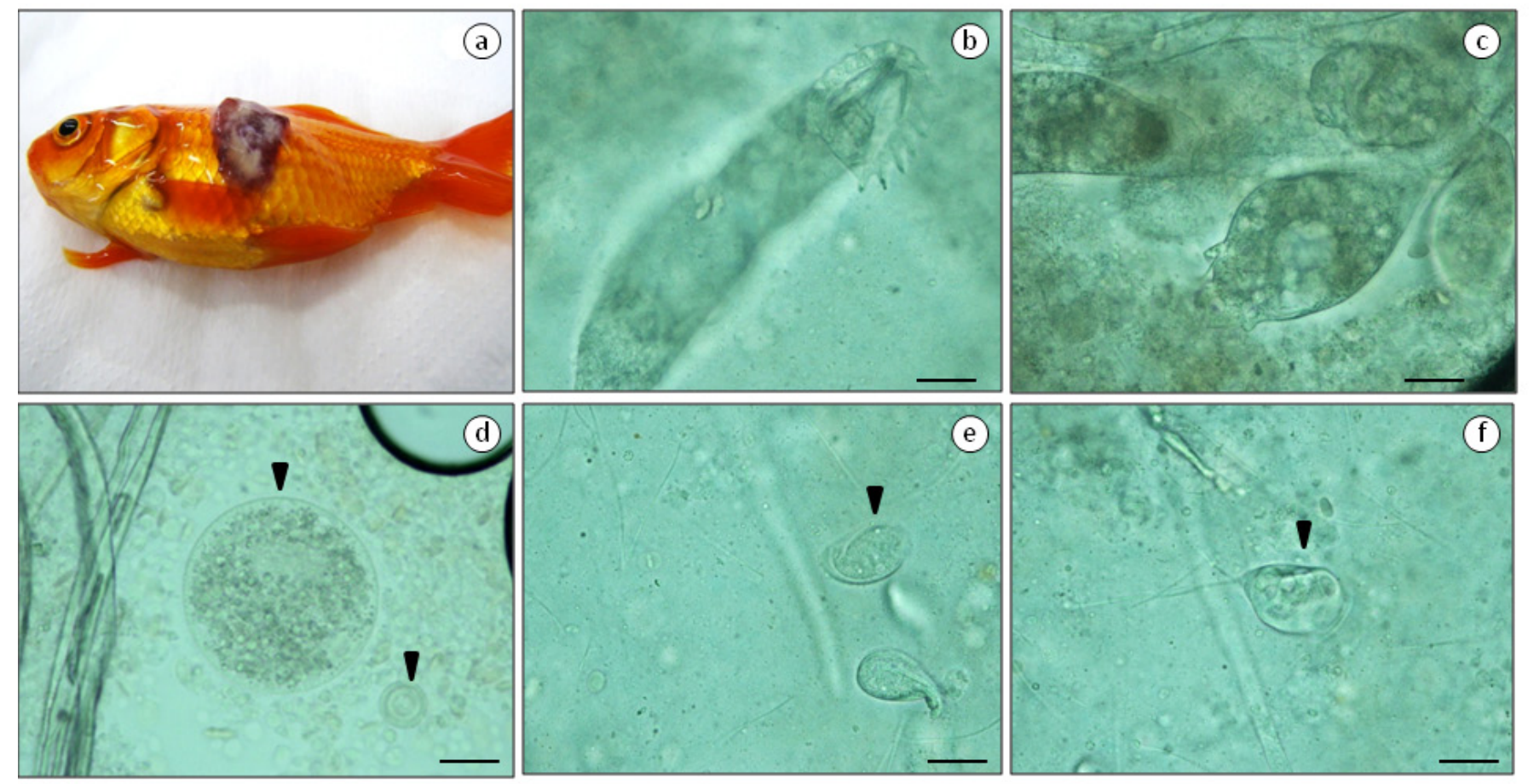

Figure 1. Light microscopy of specimens collected in goldfish Carassius auratus in farmed in the State of São Paulo. (a) Skin lesion in Carassius auratus, (b) Gyrodactylidae, (c) Epistylis sp., (d) Ichthyophthirius multifliis (arrow) and Trichodina sp. (head arrow), (e) Ichthyobodo necator (arrow) and (f) Vorticella (arrow). The scale bar in: $b=25 \mu \mathrm{m} ; \mathrm{c}, \mathrm{d}, \mathrm{f}=30 \mu \mathrm{m}$ and $\mathrm{e}=5 \mu \mathrm{m}$. 

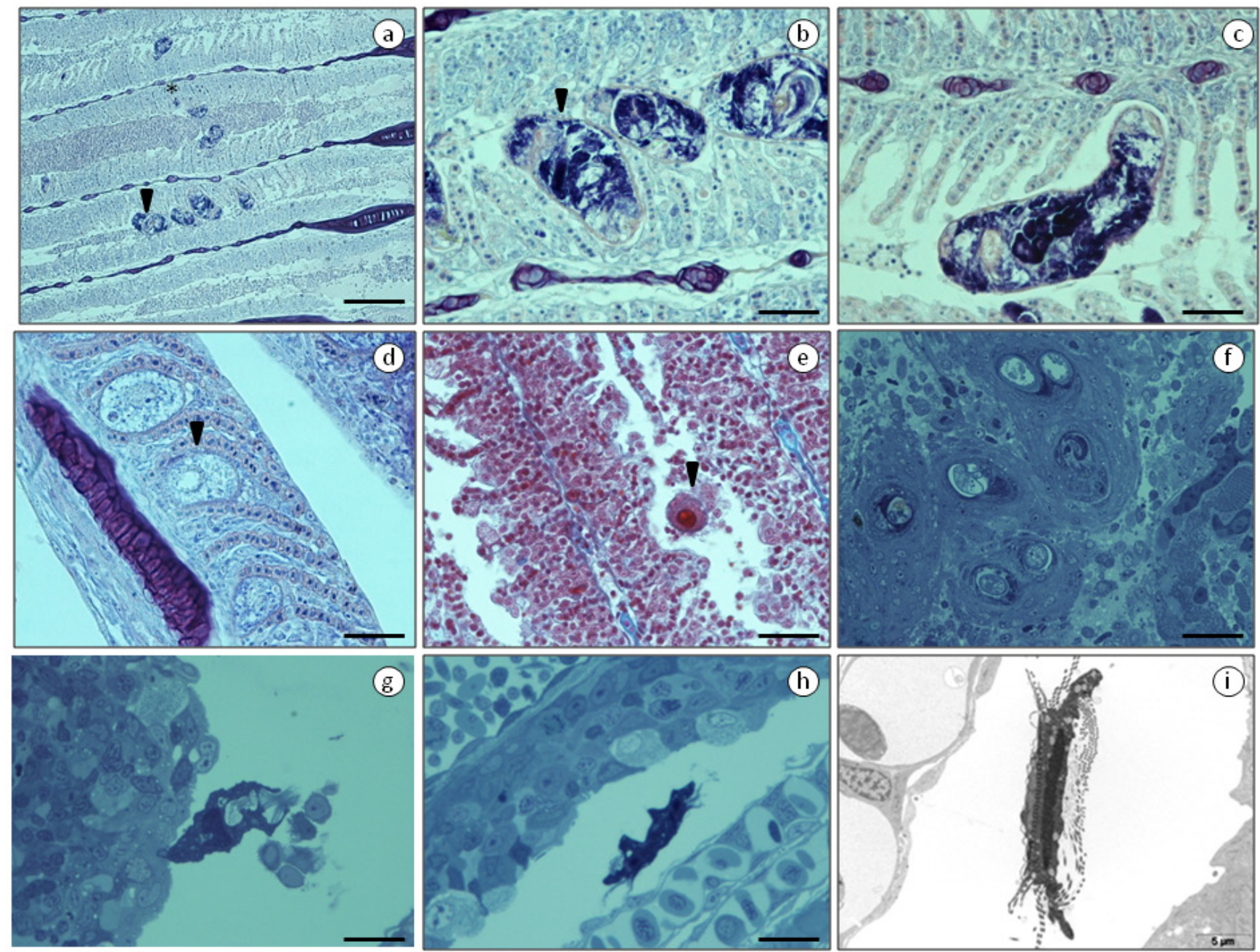

Figure 2. Histological sections of specimens collected in goldfish Carassius auratus. (a) An extensive proliferation of branchial epithelium around the invading parasites and total lamellar fusion. (b) Detail of c showing intralamellar metacercarial cysts of Digenea and (c) Monogenean Gyrodactylidae. (d) Trophonts of Ichthyophthirius multifiliis in secondary lamellae and blood vessels (arrow). (e) Tetrahymena sp. in gill. (f) Inflammatory infiltrate with lymphocytes, macrophages, neutrophils and digenea cysts in the dermis. (g) Apiosoma sp. (h) Trichodina sp. in the space between the secondary lamellae of the gills. (i) Detail of e showing Trichodina sp. in gill. The scale bar in: $a, b, c, d, e, f, g=200 \mu m$ and $\mathrm{h}, \mathrm{i}=5 \mu \mathrm{m}$.

Table 1. Prevalence of parasites observed in skin and gill lesions of goldfish Carassius auratus (Linnaeus, 1758), in the state of São Paulo, Brazil.

\begin{tabular}{ccc}
\hline Parasites & $\begin{array}{c}\text { Positive number of } \\
\text { fish with skin } \\
\text { lesions (\%) }\end{array}$ & $\begin{array}{c}\text { Positive number of } \\
\text { fish with parasites } \\
\text { in gill (\%) }\end{array}$ \\
\hline Gyrodactylidae & $28(93.4)$ & $25(83.4)$ \\
Digenea cysts & $16(53.4)$ & $14(46.6)$ \\
Epistylis sp. & $30(100)$ & - \\
Vorticella sp. & $3(10)$ & $3(10)$ \\
Trichodina sp. & $30(100)$ & $22(73.4)$ \\
Ichthyophthirius & $30(100)$ & $30(100)$ \\
multifilis & & - \\
Tetrahymena sp. & $5(16.7)$ & - \\
Ichthyobodo necator & $12(40)$ & $5(16.7)$ \\
Piscinoodinium sp. & - & $4(13.4)$ \\
Hexamita sp. & - & $6(20)$ \\
Apiosoma sp. & - & \\
\hline
\end{tabular}

was identified by its pyriform or ovoid shape and a prominent oval macronucleus that was visible in Hematoxilin-Eosin stained sections.

Trophont Piscinoodinium sp. was attached to the gills and had an ovoid, pyriform or sac-like appearance and a single eccentric nucleus without visible flagella. In smears of fresh gills, trophont chloroplasts were apparent (Figure 3b). Ichthyobodo necator was only observed in the fresh smears of skin and gill lesions. The free-swimming stage was oval or kidney-shaped and ranged between 10 and $15 \mu \mathrm{m}$ in length (Figure 1e). The flagellate protozoa of the genus Hexamita were found in the gills and was identified by its piriform body shape ( 5 to $20 \mu \mathrm{m}$ in length) and the presence of 8 long flagella (one and a half times their body length), of which 6 were located in the anterior region and two in the posterior region (Figure 3a).

Also found oval structures that were encased by a tissue layer and sucker-like organs and internal structures that featured 

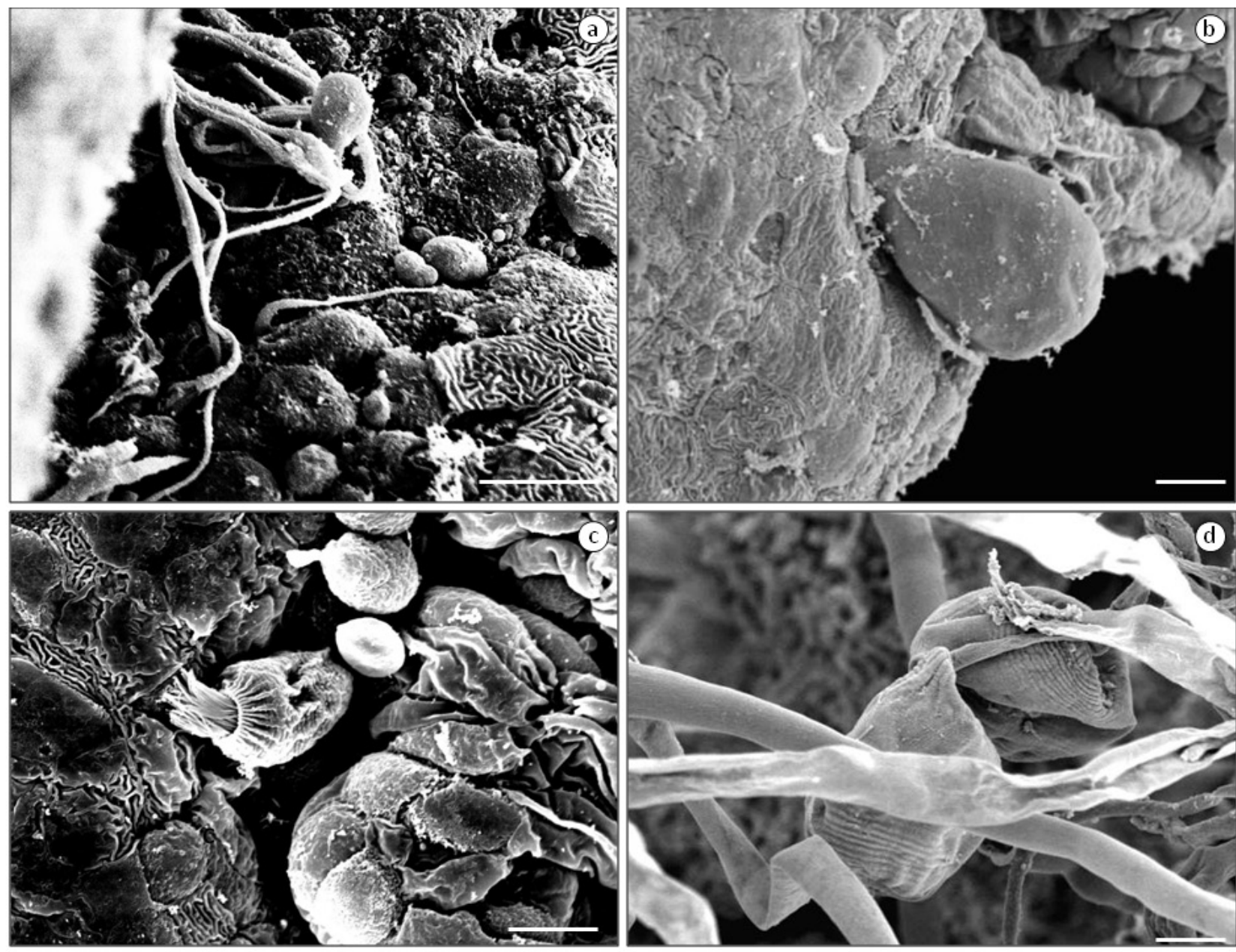

Figure 3. Scanning electron microscopy of goldfish Carassius auratus. (a) Hexamita sp., (b) trophont of Piscinoodinium sp. attached to the gill, (c) Apiosoma sp., (d) Epistylis sp. is shown in the skin. The scale bar in: a, b, c = $10 \mu \mathrm{m}$ and d $=20 \mu \mathrm{m}$.

metacercariae encysted in the gill epithelium. However, due to the tissue characteristics, it was not possible to identify the specific digeneans present in fish (Figure 2b). In skin and gills, monogenetic Gyrodactylidae with elongated bodies (approximately $1 \mathrm{~mm}$ long) present haptor later with hooks smears were identified in the histological sections of the skin and gills (Figure 2c).

\section{Discussion}

Disease in fishes is closely linked to environmental stress (BARBER, 2007). Alkaline $\mathrm{pH}$ and high ammonia concentrations, found during the analysis of the tank water from the farms, contribute to the unfavorable environmental conditions within tanks. Pavanelli et al. (2008) reported that a hight concentration of ammonia is extremely toxic to fish, particularly in combination with alkaline $\mathrm{pH}$. Furthermore, high population density reduces fish growth and promotes disease transmission, as observed here.

The gills are generally considered to be good indicators of water quality and a model for studies of environmental impacts on fish (CAMARGO \& MARTINEZ, 2007). In this study, it became clear that the unfavorable environmental conditions within tanks promoted the presence of several parasites, especially because many of these parasites were saprophytes and normally live symbiotically with healthy fish. Macroscopic lesions were not found on the gills and many histopathological changes associated with parasites were observed, reinforcing the suitability of gills as indicators of water quality. An additional of this study was that macroscopic changes were not observed, gills were not intensely infected by parasites and histopathology was severely altered, and it is clear that microscopic examination of gills scrapes and histopathology are essential for parasite identification.

Of all fish parasites, protozoa are the most dangerous and probably cause more diseases in fish cultures than any other (LOM \& DYKOVA, 1992; ABOWEI et al., 2011). Ciliates, particularly sessilines such as Apiosoma, Scopulata, Ambiphrya and Epistylis, are obligate parasites that utilize fish gills and skin as a substrate for attachment and thereby cause massive destruction. Even moderate infection of these parasites on small fish may prove fatal because the infection may cause the fish to stop feeding (ABOWEI et al., 2011). Epistylis sp. primarily appears on the tips of both dorsal and pectoral fin spines. Of the fish we studied, these exact locations exhibited cutaneous lesions, indicating that Epistylis sp. was a major pathogen. This ciliophoran is potentially harmful in large numbers, especially by physically covering gill tissues and impeding gas exchange. Fish infected with this pathogen 
are lethargic and have increased mortality, which reduces their productivity (PÁDUA et al., 2013).

The adhesive discs of Trichodina sp. attach to the epithelial surface and thereby presumably impair host cell respiration, energy production, and cell survival. In a heavily infected fish, their adherence and suction to the epithelium may cause enough damage to produce the clinical signs of anorexia, lethargy and weight loss (NOGA, 2010). The fish examined in this study had Trichodina sp. infections and also exhibited these symptoms.

In 2008, Li et al. (2008) reported that a total of 72 species and one subspecies of Apiosoma were identified. These species may be considered either as ectocommensal or ectoparasites (REDA, 2011). In this study was observed Apiosoma sp., in addition to other parasites.

The most common diseases of freshwater fish, and virtually all freshwater fish are susceptible to infection. Up to $100 \%$ mortality may occur (NOGA, 2010; WEI et al., 2013). In current study, all fish examined had I. multifiliis in their skin and gills, in addition to other parasites. The presence of this parasite in the gills increased mucus production and induced filament hyperplasia, which is in agreement with previously observed results (DICKERSON, 2012; WOO \& BRUNO, 2011).

In this study, Tetrahymena sp. was found only in 5 animals and was associated with skin lesions. In ornamental fish species previously reported to be infected with Tetrahymena sp. was include Danio rerio, Pterophyllum scalare), Paracheirodon innesi and others (PONPORNPISIT et al., 2000; ASTROFSKY et al., 2002).

The bodonid flagellate $I$. necator cause of morbidity and mortality in fishes aquaculture. This parasite is usually restricted to the protected areas on fish gills, pectoral and pelvic fins, and on areas adjacent to the dorsal fin (REAVILL \& ROBERTS, 2007). Differently, in this study, I. necator was observed only in skin and gills lesions. The species of the genus Ichthyobodo induces significant epithelial cell hyperplasia and hypertrophy, with eventual exhaustion of mucous cells, and epidermal sloughing (REAVILL \& ROBERTS, 2007). Being in agreement with these authors because describes similar parasite locations and parasite-induced types of injury in goldfish.

Hexamita sp. is considered a opportunistic parasites. The presence of these organisms in fish skin tissue is likely related to low water quality and inadequate sanitary management. The results presented here support this hypothesis since the poor water quality was characterized by high $\mathrm{pH}$ and high concentration of ammonia, thereby creating the conditions for favoring these parasites. The protozoan Hexamita sp. has been associated with tissue necrosis (MARCHIORI \& MARTINS, 2013).

Thilakaratne et al. (2003) commented that Gyrodactylidae are the most common and prevalent ectoparasite and can produce severe widespread disease in aquaculture and that, the morbidity and mortality caused by excessive dactylogyrids parasite loads are common in cultured fishes and have also occurred in wild fishes (THILAKARATNE et al.; 2003; KENT \& FOURNIE, 2007). This is in accordance with this authors because was observed high number of Gyrodactylidae lesions on the skin and gills of fish during live exams and under light microscopy. The fish infected with Dactylogyrus had clinical symptoms that included lethargy, unilateral swimming, erosion of gill filaments and scale loss (KENT \& FOURNIE, 2007). Similar changes have being described in this study. Shinn et al. (2004) recorded gill filament fusion, secondary filament hyperplasia and aneurism were reported in fish that were infected by Dactylogyrus sp. which agrees with results obtained in this study.

Digenetic larvae, such as those found in this study, are more pathogenic than the corresponding adult parasites. Their deleterious effects on fish depend on numerous factors, such as the parasite species involved, the degree of infection/infestation and the affected organ. In gills, cysts usually cause cell hyperplasia, disruption of the structures of the gill filament and, consequently, changes in gas exchange that may be fatal in high-density infestations (PAVANELLI et al., 2008).

Multiple and simultaneous ectoparasites infestations in goldfish were usually associated with skin lesions and attribute this parasitism to adverse environmental conditions and inadequate management. Ciliates and flagellate protozoans and Platyhelminthes were the most prevalent parasites, reinforcing the pathogenic and opportunistic characters of these parasites on the external surfaces of fish. This study is the first to report that Vorticella sp. was found in the gills of Carassius auratus in Brazil. It is important to note that Vorticella sp. is a facultative parasite, and its presence is related to very poor environmental conditions. This is the second report of Hexamita sp. in Brazil; however, this is the first report is associated with gill lesions.

\section{Acknowledgements}

We thank Magna Aparecida Mautauro Soares (Instituto Butantan) for making the material for light microscopy and Michelle Sanchez Freitas Correia (Universidade Paulista - Laboratório de Odontologia) for performing the scanning electron microscopy. We thank the Instituto Butantan for allowing us to use their electron microscope obtained by FAPESP project number 18070806074 .

\section{References}

Abowei JFN, Briyai OF, Bassey SE. A review of some basic parasite diseases in culture fisheries flagellids, dinoflagellides and ichthyophthriasis, ichtyobodiasis, coccidiosis trichodiniasis, heminthiasis, hirudinea infestation, crustacean parasite and ciliates. Br J Pharmacol Toxicol 2011; 2(5): 213-226.

Ashley PJ. Fish welfare: current issues in aquaculture. Appl Anim Behav Sci 2007; 104(3-4): 199-235. http://dx.doi.org/10.1016/j. applanim.2006.09.001

Astrofsky KM, Schech JM, Sheppard BJ, Obenschain CA, Chin AM, Kacergis MC, et al. High mortality due to Tetrahymena sp. infection in laboratory-maintained zebrafish (Brachydanio rerio). Comp Med 2002; 52(4): 363-367. PMid:12211282.

Barber I. Parasites, behaviour and welfare in fish. Appl Anim Behav Sci 2007 104(3-4): 251-264. http://dx.doi.org/10.1016/j.applanim.2006.09.005.

Brinn RP, Marcon JL, McComb DM, Gomes LC, Abreu JS, Baldisseroto B. Stress responses of the endemic freshwater cururu stingray (Potamotrygon cf. histrix) during transportation in the Amazon region of the Rio Negro. Comp Biochem Physiol A Mol Integr Physiol 2012; 162(2): 139-145. http:// dx.doi.org/10.1016/j.cbpa.2011.07.004. PMid:21777687. 
Camargo MMP, Martinez CBR. Histopathology of gills, kidney and liver of a Neotropical fish caged in an urban stream. Neotrop Ichthyol 2007; 5(3): 327-336. http://dx.doi.org/10.1590/S1679-62252007000300013.

Clesceri LS, Greenberg AE, Eaton AD. Standard methods for the examination of water and wastewater. 20th ed. Washington: American Public Health Association; 1998.

Dickerson HW. Ichthyophthirius multifliis. In: Woo PTK, Bruno DW, editors. Fish diseases and disorders viral, bacterial and fungal infections. Wallingford: CABI; 2012. p. 55-72.

El-Matbouli M, Hoffmann RW. Light and electron microscopic descriptions of Sphaerospora coregoni EI-Matbouli, Hoffmann and Kern, 1995 (Myxosporea: Sphaerosporidae) from the kidney of Whitefish (Coregonus lavaretus). Eur J Protistol 1996; 32(3): 389-398. http://dx.doi. org/10.1016/S0932-4739(96)80063-0.

Kent ML, Fournie JL. Parasites of fishes. In: Baker DG, editor. Flynn's parasites of laboratory animals. Hoboken: Blackwell; 2007. p. 69-116.

Li M, Wang J, Zhu D, Gu Z, Zhang J, Gong X. Study of Apiosoma piscicola (Blanchard 1885) occurring on fry of freshwater fishes in Hongze, China with consideration of the genus Apiosoma. Parasitol Res 2008; 102(5): 931-937. http://dx.doi.org/10.1007/s00436-007-0856-5. PMid:18247054.

Lom J, Dykova L. Protozoan parasites of fishes - developments in aquaculture and fisheries science. Amsterdam: Elsevier; 1992.

Marchiori NC, Martins ML. Flagellata. In: Pavanelli GC, Takemoto RM, Eiras JC, editors. Parasitologia de peixes de água doce do Brasil. Maringá: Eduem; 2013. p 201-216.

Neiffer DL, Stamper MA. Fish sedation, anesthesia, analgesia and euthanasia: considerations, methods, and types of drugs. ILAR J 2009; 50(4): 343-360. http://dx.doi.org/10.1093/ilar.50.4.343. PMid:19949251.

Noga EJ. Fish disease: diagnosis and treatment. Iwoa: Wiley-Blackwell; 2010.

Pádua SB, Ishikawa MM, Ventura AS, Jerônimo GT, Martins ML, Tavares LER. Brazilian catfish parasitized by Epistylis sp. (Ciliophora, Epistylididae), with description of parasite intensity score. Parasitol Res 2013; 112(1): 443-446. http://dx.doi.org/10.1007/s00436-012-3069-5. PMid:22890898.

Pavanelli GC, Eiras JC, Takemoto RM. Doenças de peixes: profilaxia, diagnóstico e tratamento. Maringá: Eduem; 2008.
Ponpornpisit A, Endo M, Murata H. Experimental infections of a ciliate Tetrahymena pyriformis on ornamental fishes. Fish Sci 2000; 66(6): 10261031. http://dx.doi.org/10.1046/j.1444-2906.2000.00164.x.

Purivirojkul W, Boonsoong B. A new species of Tetraphyllidean (Onchobothriidae) cestode from the brown-banded bambooshark Chiloscyllium punctatum (Elasmobranchii: Hemiscylliidae). J Parasitol 2012; 98(6): 1216-1219. http://dx.doi.org/10.1645/GE-3084.1. PMid:22681175.

Reavill D, Roberts H. Diagnostic cytology of fish. Vet Clin North Am Exot Anim Pract 2007; 10(1): 207-234, vii. http://dx.doi.org/10.1016/j. cvex.2006.11.002. PMid:17198965.

Reda ESA. A review of some ecto- and endoprotozoan parasites infecting Sarotherodon galilaeus and Tilapia zillii from Damietta branch of River Nile, Egypt. J Amer Sci 2011; 7(3): 362-373.

Roberts HE, Palmeiro B, Weber ES 3rd. Bacterial and parasitic diseases of pet fish. Vet Clin North Am Exot Anim Pract 2009; 12(3): 609-638. http://dx.doi.org/10.1016/j.cvex.2009.06.010. PMid:19732712.

Shinn AP, Hansen H, Olstad K, Bachmann L, Bakke TA. The use of morphometric characters to discriminate specimens of laboratory-reared and wild populations of Gyrodactylus salaris and G. thymalli (Monogenea). Folia Parasitol (Praha) 2004; 51(2-3): 239-252. http://dx.doi.org/10.14411/ fp.2004.029. PMid:15357403.

Silva SS, Turchini GM. Towards understanding the impacts of the pet food industry on world fish and seafood supplies. J Agric Environ Ethics 2008; 21(5): 459-467. http://dx.doi.org/10.1007/s10806-008-9109-6.

Thilakaratne ID, Rajapaksha G, Hewakopara A, Rajapakse RP, Faizal AC. Parasitic infections in freshwater ornamental fish in Sri Lanka. Dis Aquat Organ 2003; 54(2): 157-162. http://dx.doi.org/10.3354/ dao054157. PMid:12747641.

Wei JZ, Li H, Yu H. Ichthyophthiriasis: emphases on the epizootiology. Lett Appl Microbiol 2013; 57(2): 91-101. http://dx.doi.org/10.1111/ lam.12079. PMid:23565747.

Woo PTK, Bruno DW. Fish diseases and disorders viral, bacterial and fungal infections. Wallingford: CABI; 2011.

Woo PTK, Buchmann K. Fish parasites, pathobiology and protection. Cambridge: CABI; 2012. 